\title{
Histomorphology and Physical Characteristics of Buffalo Meat at Different Sex and Age
}

\author{
H. Nuraini ${ }^{\mathrm{a}, *}$, Mahmudah ${ }^{\mathrm{a}}$, A. Winarto ${ }^{\mathrm{b}}$, \& C. Sumantri ${ }^{\mathrm{a}}$ \\ ${ }^{a}$ Departement of Animal Production and Technology, Faculty of Animal Science, Bogor Agricultural University \\ bDepartement of Anatomy and Physiology, Faculty of Veterinary Medicine, Bogor Agricultural University \\ Jln. Agatis, Kampus IPB Darmaga, Bogor, 16680, Indonesia \\ (Received 12-10-2012; Reviewed 23-11-2012; Accepted 23-01-2013)
}

\begin{abstract}
The aim of this experiment was to evaluate histology and physical variables of buffalo meat at different sex and ages. Thirty head of buffaloes were used in this experiment. Muscle fiber diameter, fasciculus diameter, thickness of connective tissue, $\mathrm{pH}$, water holding capacity, Warner-Bratzler shear force and cooking loss were measured in this experiment. Analysis of variance of randomized factorial design was used to analyse the data. The differences were analysed by Tukey test. The result showed that muscle fiber diameter was influenced by ages. The difference muscle fiber diameter among ages indicated that 8-12 mo and $1.5 \mathrm{yr}$ old have smaller diameter compared to three year old $(\mathrm{P}<0.05)$, but there was no differences between two, three and four years old. The fasciculus diameter, thickness of connective tissue, tenderness, $\mathrm{pH}$ value, water holding capacity, and cooking lost indicated no significant found in all stage of age and sex of samples. Meat qualities of buffaloes were not affected by age (2-4 yr) and sex.
\end{abstract}

Key words: histomorphology, buffalo, meat quality, muscle fiber diameter, tenderness

\section{ABSTRAK}

Tujuan penelitian ini adalah untuk mengevaluasi variabel histologi dan karakteristik fisik daging kerbau pada jenis kelamin dan umur yang berbeda. Tiga puluh ekor kerbau digunakan dalam penelitian ini. Peubah yang diukur adalah diameter serabut otot, diameter fasikulus, ketebalan jaringan ikat, $\mathrm{pH}$, daya mengikat air, tingkat keempukan (daya iris) dan susut masak. Rancangan acak lengkap pola faktorial digunakan untuk menganalisis data. Perbedaan antara perlakuan dianalisis dengan uji Tukey. Hasil penelitian menunjukkan bahwa ukuran diameter serabut otot dipengaruhi oleh umur. Perbedaan diameter serabut otot antar umur menunjukkan bahwa umur 8-12 bulan dan 1,5 tahun memiliki diameter serabut otot yang lebih kecil dibandingkan dengan umur tiga tahun tapi tidak terdapat perbedaan diantara umur 2, 3, dan 4 tahun. Peubah diameter fasikulus, tebal jaringan ikat, keempukan, nilai $\mathrm{pH}$, daya mengikat air dan susut masak menunjukkan bahwa tidak ada perbedaan diantara umur dan jenis kelamin. Kualitas daging kerbau tidak dipengaruhi oleh umur (2-4 tahun) dan jenis kelamin.

Kata kunci: histomorfologi, kerbau, kualitas daging, diameter serabut otot, keempukan

\section{INTRODUCTION}

Buffaloes in special circumstances are considered luxurious by the Indonesian community in Banten, West Sumatra, North Sumatra, South Sulawesi and West Java. Some consumers like buffalo's meat even though it is tougher than beef, because it has a special method of cooking. Funeral ceremony in Tana Toraja, South Sulawesi, placed buffaloes as sacrificed animal so that the buffalo's position become very important in the society.

${ }^{*}$ Corresponding author:

E-mail: hennynuraini@ymail.com
Buffalo's meat is less desirable compared with beef because the buffalo were slaughtered from older animals (aged 8-10 yr) and used as a draught so that meat produced is tough, no juicy, less of flavour and not attractive. This causes the buffalo's meat does not qualify as good quality meat. Tenderness of meat is influenced by several factors such as the state of the muscle fibers, feed, livestock activities and treatment before and after slaughter. According to Rao et al. (2009) age and sex of animals also affect the quality of meat. The old animals will change the structure of the connective tissue and meat become tough, thus increasing the value of toughness. Xiong et al. (2007) states that the value of toughness is affected by age and postmortem 
storage time, due to chemical changes in the muscle at refrigerator temperature. Shear force value increased with age and decreased with the increasing of storage time up to 10 days because of the split of muscle fibers. Rao et al. (2009) also stated the same thing that there is a significant effect on the age and sex of the shear force value at different storage periods. Shear force value tends to increase in older buffaloes due to the development of connective tissue. Female buffalo's meat is more tender than males.

Meat would have biochemical and physicochemical changes such as changes in the structure of muscle tissue, $\mathrm{pH}$, protein, and changes in water holding capacity. According to Aberle et al. (2001), factors that affect meat quality of consumer acceptance are including color, tenderness and texture, flavour and aroma, intramuscular fat, cooking loss, $\mathrm{pH}$, and water holding capacity. Various studies have been conducted to improve the quality of buffalo's meat. Spanghero et al. (2007) explained that buffalo's intramuscular fat exhibited higher $(\mathrm{P}<0.01)$ saturated fatty acid (FA) percentage than bovine $(44.4 \%$ vs. $36.9 \%)$, owing to a greater concentration of stearic acid $(21.5 \%$ vs. $14.4 \%)$, and less $(\mathrm{P}<0.01)$ polyunsaturated fatty acid (PUFA) levels (18.6\% vs. $28.6 \%)$, with a significantly higher n6-PUFA/n3-PUFA ratio (16.7 vs. 12.3). The overall acceptability of buffalo and bovine raw meat did not differ significantly, but the tenderness of beef meat was perceived to be significantly better than buffalo. Neath et al. (2007b) shows that there was no difference in calpastatin activity, and no major differences were observed in calpains 1, 2, and calpastatin expression by Western blotting. The higher calpastatin activity in early postmortem was responsible for the increase tenderness of water buffalo meat compared to beef.

Histomorphology is the study of the size of the organ, tissue or tissue sections by means of observation and study. The importance of information on muscle and connective tissue as the main constituent components and determine the quality of the meat, causing need to do an analysis of the influence of age and sex on histomorphology and physical properties of buffalo meat. The objective of this study was to determine the effect of sex and age to the histomorphology and physical characteristics of buffalo's meat.

\section{MATERIALS AND METHODS}

\section{Procedure Sampling Techniques}

Buffalo's meat samples were obtained from traditional slaughter houses in 11 districts of Banten province. Meat samples were obtained from the Longissimus dorsi muscle in rib 12-13 stored at freezing temperatures $\left(-12{ }^{\circ} \mathrm{C}\right)$ for $1-2$ mo. The samples were analyzed their physical characteristics and histomorphology.

\section{Histological Preparations}

This stage began with a sampling of buffalo's meat for $1 \times 1 \times 0.5 \mathrm{~cm}^{2}$. Meat samples were fixed with $4 \%$ of paraformaldehyde. The purpose of fixation was to discontinue the process of metabolic and prevent autolysis or tissue preservation. The process of histological preparations refered to Kiernan (1990).

\section{Observed Variables}

Buffalo's muscle histomorphology. Observations were made under a light microscope equipped with a micrometer-scale peace eye. The variables measured were the diameter of the muscle fibers and fasciculus, and the distance between fasciculus or thickness of connective tissue. Diameter of muscle fibers was determined by measuring perpendicularly each of the three muscle fibers in three fasciculus of each sample. The measurement results were then averaged. Fasciculus diameter measured perpendicular at three different visual field of each sample and then averaged the results. The thickness of connective tissue was measured across the connective tissue that does not decompose in three different fields of view and averaged the results.

Physical characteristics of buffalo meat. Meat $\mathrm{pH}$ value was measured by a pH meter by AOAC (1995) method. Measurements were taken three times per sample by inserting a $\mathrm{pH}$ meter into the meat samples. Water holding capacity was calculated based on the percentage of water that comes out $\left(\mathrm{mg} \mathrm{H}_{2} \mathrm{O}\right)$ by the method of Hamm (1972). This method was done by applying pressure on a sample of $0.3 \mathrm{~g}$ placed on filter paper between two plates of Carver Press. The process of suppression was performed for $5 \mathrm{~min}$ with a load of $35 \mathrm{~kg} / \mathrm{cm}^{2}$. Area covered by the sample and the surrounding wet areas were marked and then measured with a planimeter. Wet area was the area of water absorption on filter paper samples minus the covered area. Figures obtained from the equation were then converted to the weight of the sample of $0.3 \mathrm{~g}$. The greater the value obtained indicates lower water binding capacity. Water holding capacity was calculated by the following equation:

$$
\begin{aligned}
& \left.\mathrm{mg} \mathrm{H}_{2} \mathrm{O}=\text { [width of wet area }\left(\mathrm{cm}^{2}\right) / 0.0948\right]-8.0 \\
& \% \text { of free water }=\left(\mathrm{mg} \mathrm{H}_{2} \mathrm{O} / 300\right) \times 100 \%
\end{aligned}
$$

Description:

$0.0948 \mathrm{mg} \mathrm{H}_{2} \mathrm{O}=$ constant formula

$300=$ conversion yield of $0.3 \mathrm{~g}$ to $\mathrm{mg}$

Tenderness of the meat were analyzed using the method of slices (Aberle et al., 2001). The variable of meat was obtained by using a sample of $100 \mathrm{~g}$ of boiled meat until internal temperature of the meat at $80-82{ }^{\circ} \mathrm{C}$. The meat was then cooled until a constant weight. The meat was then shaped using a corer unidirectional fiber of the meat. Pieces were then determined by the value of the power breakdown Warner Bratzler device with unit conversions in $\mathrm{kg} / \mathrm{cm}^{2}$. The results of measurements on a scale of $1-2 \mathrm{~kg} / \mathrm{cm}^{2}$ into the category of very soft, the scale of $3-5 \mathrm{~kg} / \mathrm{cm}^{2}$ in the category of soft, $5-9 \mathrm{~kg} / \mathrm{cm}^{2}$ in the category of hard and more than $9 \mathrm{~kg} / \mathrm{cm}^{2}$ in the category of very hard.

Cooking loss was evaluated by the percentage of weight differences before and after cooking to the 
weight before cooking. Meat was weighed to obtain initial weight, and stewed until the final temperature of $80-82{ }^{\circ} \mathrm{C}$, then cooled until it reached a constant weight. The percentage of cooking loss determined using the equation:

$\%$ Cooking loss $=[($ initial weights - the constant weights of sample)/ initial weights] x $100 \%$

\section{Design and Data Analysis}

Experimental design used in this study was a completely randomized factorial design $2 \times 5$ with 3 replications. The first factor was sex (male and female) and the second factor was age of buffaloes, i.e. 8-12 mo, $1.5,2,3$, and 4 yr old. The data obtained were analyzed using analysis of the range and if there was a significant difference $(\mathrm{P}<0.05)$, followed by the Tukey test (Steel \& Torrie, 1991).

\section{RESULTS AND DISCUSSION}

\section{Buffalo's Meat Histomorphology}

The diameter of muscle fibers. The muscle fibers diameter was presented in Table 1. Increased age can affect the diameter of muscle fibers of buffalo. The results showed that the diameter of the muscle fibers was high at three years of age both male and female. Muscle fiber diameter increased gradually until it reaches the highest value at three years of age and decreased at four years of age. The diameter of muscle fibers of female was higher than male buffalo. The condition was thought to be related to differences in growth patterns between males and females, management of maintenance and handling of livestock during and after slaughter. Female buffalo's meat at 8-12 mo had smaller muscle fibers than male buffalo's meat because of the binding of water from male buffalo's meat was larger than females at the same age. Water holding capacity were expressed the ability of muscle fiber to binding water molecules that made wider diameter of muscle if they had high water holding capacity). The diameter of the muscle fibers of the buffalo's meat was shown in Figure 1.

The diameter of muscle fibers in the area of Banten was influenced by differences in age, but not influenced by sex. Muscle fibers of buffaloes aged 8-12 mo and $1.5 \mathrm{yr}$ old had a diameter smaller than the diameter of the muscle fibers of buffalo's meat at 3 yr old $(\mathrm{P}<0.05)$, and no difference between the age of 2, 3, and 4 yr old. Rao et al. (2009) stated the same thing that the diameter of the muscle fibers was not affected by sex, but was influenced by age of the buffalo. According to Choi \& Kim (2009) muscle fiber diameter increased with age, level of nutrition, postnatal development and the level of muscle performance.

The diameter of fasciculus. Muscle is composed of many individual fibres that are grouped together into bundles or fasciculi, a fascicle is a bundle of skeletal muscle fibers surrounded by perimysium (Aberle et al., 2001). Organizational of muscle morphology was myofibrils, muscle fibers and fasciculus (Figure 2). Data analysis of fasciculus diameter of buffalo meat were shown in Table 2. The highest score of fasciculus diameter of male buffalo muscle was at three years old and decreased

Table 1. Muscle fibers diameter of buffalo meat at different sex and age $(\mu \mathrm{m})$

\begin{tabular}{ccccccc}
\hline \multirow{2}{*}{ Sex } & \multicolumn{9}{c}{ Age } \\
\cline { 2 - 7 } & $8-12 \mathrm{mo}$ & $1.5 \mathrm{yr}$ & $2 \mathrm{yr}$ & $3 \mathrm{yr}$ & $4 \mathrm{yr}$ & Mean \\
\hline Female & $37.24 \pm 1.3$ & $39.65 \pm 8.0$ & $47.39 \pm 7.2$ & $55.67 \pm 8.6$ & $52.83 \pm 1.8$ & $46.56 \pm 9.1$ \\
Male & $39.39 \pm 2.0$ & $35.09 \pm 9.1$ & $45.00 \pm 10.3$ & $54.24 \pm 10.4$ & $45.47 \pm 6.3$ & $43.84 \pm 9.7$ \\
Mean & $38.32 \pm 1.9^{\mathrm{a}}$ & $37.37 \pm 8.0^{\mathrm{a}}$ & $46.20 \pm 8.0^{\mathrm{ab}}$ & $54.95 \pm 8.6^{\mathrm{b}}$ & $49.15 \pm 5.8^{\mathrm{ab}}$ & $45.20 \pm 9.3$ \\
\hline
\end{tabular}

Note: Means in the same row with different supercript differ significantly $(\mathrm{P}<0.05)$
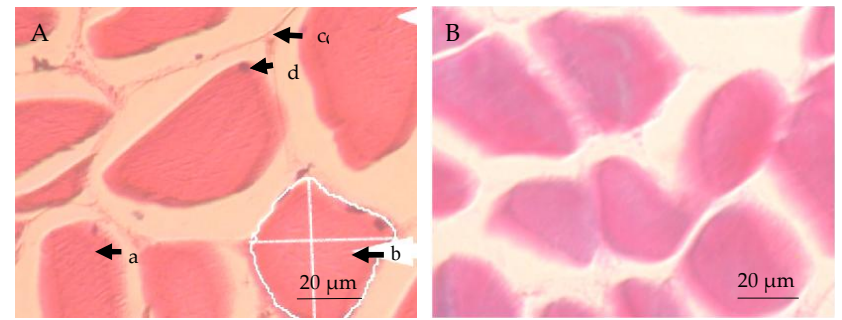

Figure 1. Muscle fibers diameter of male buffalo meat. A= Largest diameter muscle fibers at 3 yr old treated Hemactosilin Eosin (HE), B= Lowest diameter muscle fibers at $1.5 \mathrm{yr}$ old with Casson Trichrome staining (CT). Arrow $\mathrm{a}=$ myofibrils, $\mathrm{b}=$ muscle fibers, $\mathrm{c}=$ endomisium, and $\mathrm{d}=$ cell nucleus.

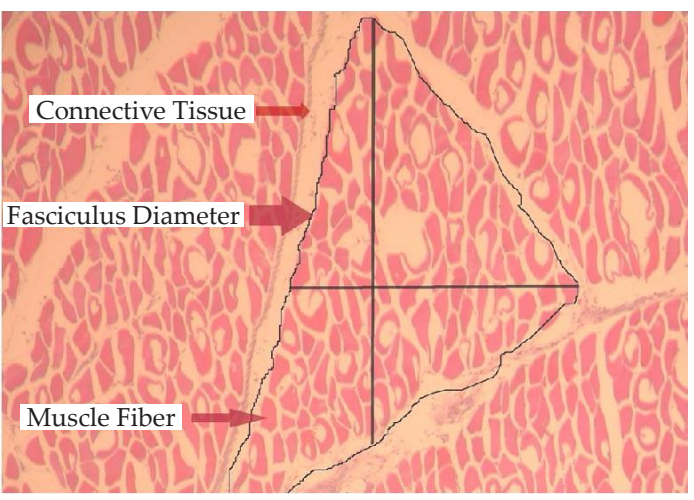

Figure 2. Transverse cross section of muscle structure with Hemactocilin Eosin staining 
Table 2. Diameter fasciculus of buffalo meat at different sex and age $(\mu \mathrm{m})$

\begin{tabular}{ccccccc}
\hline \multirow{2}{*}{ Sex } & \multicolumn{7}{c}{ Age } \\
\cline { 2 - 7 } & $8-12 \mathrm{mo}$ & $1.5 \mathrm{yr}$ & $2 \mathrm{yr}$ & $3 \mathrm{yr}$ & $4 \mathrm{yr}$ & Mean \\
\hline Female & $642.4 \pm 83.7$ & $653.3 \pm 27.2$ & $664.8 \pm 51.4$ & $700.2 \pm 143.5$ & $786.7 \pm 146.3$ & $689.5 \pm 102.1$ \\
Male & $561.0 \pm 101.0$ & $471.1 \pm 102.2$ & $646.0 \pm 217.0$ & $658.9 \pm 165.2$ & $640.1 \pm 135.7$ & $595.4 \pm 146.9$ \\
Mean & $601.7 \pm 94.2$ & $562.2 \pm 120.1$ & $655.3 \pm 141.2$ & $679.6 \pm 140.2$ & $713.4 \pm 149.6$ & $642.4 \pm 133.2$ \\
\hline
\end{tabular}

at four years old. It was related to muscle fiber diameter $(54.24 \pm 10.4 \mu \mathrm{m})$ and the distance between fibers $(8.49 \pm 1.01 \mu \mathrm{m})$. Diameter fasciculus of female buffalo muscles increased gradually until it reaches the highest at four years because it has a greater thickness of connective tissue $(18.85 \pm 7.56 \mu \mathrm{m})$, wider distance between the muscle fibers $(9.55 \pm 0.64 \mu \mathrm{m})$, and higher water holding capacity $(52.5 \% \pm 20.3 \%)$ among the age group. However, the diameter of the muscle fibers of female buffaloes at four years old were less than three years, but the thickness of the connective tissue and the distance between the muscle fibers were greater than three years old, so that female buffalo's muscle at four years old produced larger diameter of fasciculus.

The size of fasciculus was correlated with size of muscle fiber diameter, number of muscle per fasciculus, thickness of connective tissue, and the distance between the muscle fibers. The greater of diameter of muscle fibers, connective tissue thickness and diameter of fasciculus could lead to higher binding capacity of water and could cause lower cooking loss or less muscular component that comes out of the meat.

The muscle of female buffaloes at four years old and the muscle of buffalo males at three years old, had a rougher texture among all age groups. Conversely, males buffalo's muscle at $1.5 \mathrm{yr}$ old and females at 8-12 mo had smoother texture because fasciculus diameter was smaller among the four age groups buffalo. It was likely influenced by the movement of muscles in female buffalo more than male buffalo as draught animal. Aberle et al. (2001) reported that coarse texture had a large bond of muscle fibers (eg semimembranosus muscle) and fine texture with small bond of muscle fibers (eg semitendinosus muscle).

Tissue in animals has evolved with age. Fasciculus diameter growth is not due to an increase in the number of muscle fibers, but because of an increase in the number of myofibrils. The results showed that the treatment, age and sex in this study had no effect on muscle fasciculus diameter of buffalo. Aberle et al. (2001) stated that the size of a fasciculus determined by the number and size of muscle fibers and the number of perimisium and endomisium.

Collagen thickness. Connective tissue consists of basic substances, cells, and extracellular fibers. The type of connective tissue cells consists of fibroblasts, macrophages, vascular system, and mast cells. Mast cells located along the delicate branches of the lymphatic system in perimisium and endomisium (Aberle et al., 2001). Muscle connective tissue composed of epimisium located around the muscle, which lies between the perimisium fasciculus and endomisium between muscle fibers. The thickness of connective tissue on female buffalo were different between ages, which was the highest at $4 \mathrm{yr}$ old $(18.85 \pm 7.56 \mu \mathrm{m})$ and the lowest at $1.5 \mathrm{yr}$ old

Table 3. Thickness of connective tissue of buffalo meat at different sex and age $(\mu \mathrm{m})$

\begin{tabular}{ccccccc}
\hline \multirow{2}{*}{ Sex } & \multicolumn{7}{c}{ Age } \\
\cline { 2 - 7 } & $8-12 \mathrm{mo}$ & $1.5 \mathrm{yr}$ & $2 \mathrm{yr}$ & $3 \mathrm{yr}$ & $4 \mathrm{yr}$ & Mean \\
\hline Female & $15.12 \pm 1.48$ & $14.19 \pm 4.77$ & $16.80 \pm 5.62$ & $16.80 \pm 3.51$ & $18.85 \pm 7.56$ & $16.35 \pm 4.56$ \\
Male & $16.05 \pm 2.69$ & $31.10 \pm 27.40$ & $15.77 \pm 7.52$ & $20.44 \pm 7.88$ & $13.53 \pm 3.98$ & $19.38 \pm 13.02$ \\
Mean & $15.59 \pm 2.00$ & $22.63 \pm 19.88$ & $16.29 \pm 5.96$ & $18.62 \pm 5.81$ & $16.19 \pm 6.14$ & $17.86 \pm 9.71$ \\
\hline
\end{tabular}
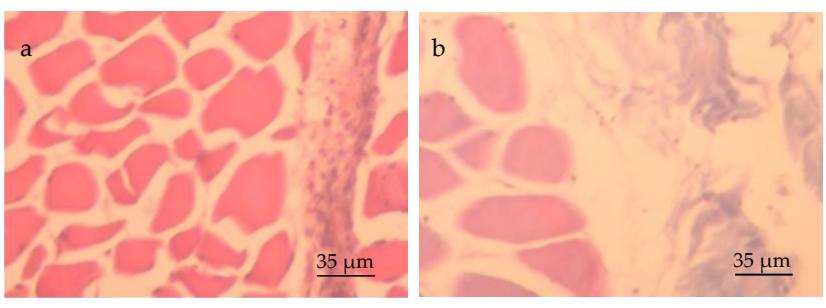

Figure 3. Thickness of connective tissue of female buffalo meat treated Casson Trichrome. $\mathrm{a}=$ thinness connective tissue at $1.5 \mathrm{yr}$ old, $\mathrm{b}=$ thickness connective tissue at $4 \mathrm{yr}$ old.

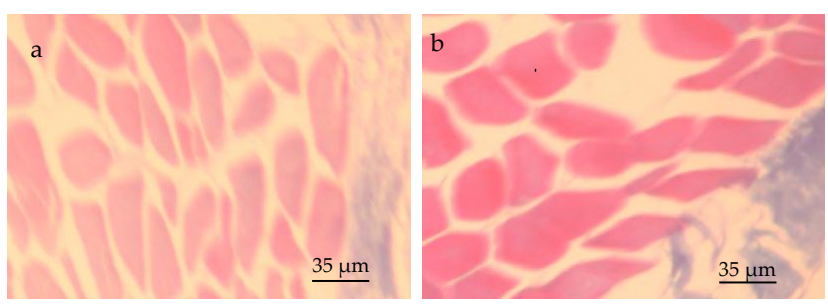

Figure 4. Thickness of connective tissue of male buffalo meat treated Casson Trichrome. $\mathrm{a}=$ thinness connective tissue at $4 \mathrm{yr}$ old; $b=$ thickness connective tissue at 1.5 yr old. 
$(14.19 \pm 4.77 \mu \mathrm{m})$, this was associated with high water holding capasity, at four years old was $52.5 \% \pm 20.3 \%$ and at 1.5 year old was $13.97 \% \pm 16.13 \%$ (Table 3 ).

Connective tissue of male buffalo was the highest at $1.5 \mathrm{yr}$ old $(31.1 \pm 27.4 \mu \mathrm{m})$ with the lowest cooking loss values was $32.9 \% \pm 7.7 \%$. Connective tissue thickness were difference between sex, which female buffalo was smaller than male buffalo because water holding capacity values of female buffalo were smaller than male buffalo. The thickness of the connective tissue of female buffalo meat increased from 1.5 yr old until 4 yr old. This situation illustrated that the increase of age would increase the thickness of the connective tissue. According to Aberle et al. (2001), it was related to the content of collagen in animal tissues. Collagen is the main protein component of the connective tissue and has a major impact on meat tenderness.

Conditions of buffalo meat tissue thickness were shown in Figure 3 and 4. Collagen concentration of 1.5 year old male buffalo $(0.82 \% \pm 0.02 \%)$ was lower than male buffalo aged over $10 \mathrm{yr}(1.54 \% \pm 0.20 \%)$, but the solubility of collagen in male buffalo ages 10 and above $(7.40 \% \pm 0.28 \%)$ was lower than the male buffalo age $1.5 \mathrm{yr}$ $(29.90 \% \pm 1.64 \%)$, causing collagen in young buffalo meat more susceptible to damage. Collagen in older buffalo was more stable on influence of temperature to form a thick connective tissue more solid and larger. Increased age was associated with increased levels of pyridinoline content. Pyridinoline levels in young animals are lower, so the content will be labile to heat collagen. It has been proved that the cross linking of connective tissue in old animals was higher and more stable against damage than those in young animals (Kandeepan et al., 2009).

Decreased thickness of the connective tissue in the female buffalo was also associated with higher levels of collagen in the muscle buffalo. According to Kandeepan et al. (2006), at the same age female buffalo collagen concentration $(1.85 \% \pm 0.25 \%)$ was higher than the male buffalo $(1.54 \% \pm 0.20 \%)$, but the male buffalo collagen solubility $(7.40 \% \pm 0.28 \%)$ was lower than female buffalo $(9.33 \% \pm 0.77 \%)$. Collagen solubility was lower in male buffalo makes collagen more resistant to the effects of temperature because of the amount of crosslinked and consistency was higher than female buffalo, resulted in tissue thickness of male buffalo was higher than females. This is probably due to the movement of muscles male buffalo that is widely used as a drought animal. Differences in age and sex in this study showed no significant effect to the thickness of the connective tissue of buffalo's meat.
During the process of animal maturation, collagen becomes more resistant to damage. This is due to an increased in the number of intramolecular crosslinked. Formation of transverse crosslinked in adult animals resulted in increased tension within the heat treatment, conversely at the young animals. Crosslinked in collagen would determine the solubility, shrinkage rate, and strength during shrinked (Aberle et al., 2001).

\section{Physical Characteristics of Buffalo's Meat}

Tenderness. Shear force values might show tenderness of meat. Tenderness is the most important determinant quality of the meat. The lowest shear force values in male and female buffaloes were under one year old including into the category of hard $\left(6.53 \pm 2.89 \mathrm{~kg} / \mathrm{cm}^{2}\right)$. Buffalo's meat tenderness under one year of age showed the meat in harsh conditions and after passing the age of $1.5 \mathrm{yr}$ showed no difference in tenderness (Table 4). Shear force value negatively correlated with meat tenderness, if the shear force values is high then the meat is less tender.

Meat with greater myofibrilar (semitendinosus) had lower tenderness than the smaller myofibrilar (longissimus dorsi) (Aberle et al., 2001). The results showed that female buffalo's meat was tougher than male buffalo's meat. Female buffalo's meat was tenderer than the male buffalo at one year old because it was associated with muscle fiber size at female buffalo was smaller than males. There was a positive correlation $(\mathrm{P}<0.05)$ between the shear force value and muscle diameter of male buffalo. It was similar to that reported Rao et al. (2009) that female buffalo meat was more tender than males buffalo meat.

Age and sex did not give a significant effect on the value of shear force of buffalo's meat in Banten area. This was an implication of the $\mathrm{pH}$ value, cooking loss, water binding capacity, connective tissue thickness, and diameter of fasciculus that were also not significantly different. Andreas et al. (2010) stated the same thing that the value of shear force of buffalo's meat was not affected by age and sex.

The difference ways of raising buffaloes in Banten may affect the observed variables. Buffaloes in Banten were maintained in different ways i.e. in stabled and in the pastures. Another factor that could affect the tenderness of meat was degradation of miofibrilar, connective tissue, sarcomere length, muscle fibers, and a decreased of pH (Neath et al., 2007a). Naveena et al. (2011) suggested that ammonium hydroxide might be used to

Table 4. Shear force value of buffalo meat at different sex and age $\left(\mathrm{kg} / \mathrm{cm}^{2}\right)$

\begin{tabular}{crrrrrc}
\hline & \multicolumn{7}{c}{ Age } \\
\cline { 2 - 7 } Sex & \multicolumn{1}{c}{ 8-12 mo } & \multicolumn{1}{c}{$1.5 \mathrm{yr}$} & \multicolumn{1}{c}{2 yr } & \multicolumn{1}{c}{3 yr } & \multicolumn{1}{c}{4 yr } & Mean \\
\hline Female & $5.89 \pm 3.54$ & $10.27 \pm 0.58$ & $10.19 \pm 1.85$ & $10.02 \pm 0.95$ & $9.65 \pm 1.11$ & $9.20 \pm 2.37$ \\
Male & $7.17 \pm 2.69$ & $8.90 \pm 2.75$ & $9.66 \pm 1.93$ & $9.23 \pm 1.96$ & $9.24 \pm 1.62$ & $8.84 \pm 2.09$ \\
Mean & $6.53 \pm 2.89$ & $9.58 \pm 1.93$ & $9.93 \pm 1.72$ & $9.63 \pm 1.45$ & $9.44 \pm 1.26$ & $9.02 \pm 2.20$ \\
\hline
\end{tabular}


tenderize tough buffalo's meat. Samples treated with $0.1 \%, 0.5 \%$, and $1.0 \%$ solution of ammonium hydroxide revealed breakdown of endothelium layers surrounding muscle fibers and weakening of Z-discs respectively, compared to controls. Other study indicated that electrical stimulation of buffalo carcasses with 440 volts current accelerated glycolysis and improved the tenderness (Kumar \& Thulasi, 2011).

Buffalo's meat pH values. Meat $\mathrm{pH}$ value influences on the resistance of high nutritious food. $\mathrm{pH}$ of male buffalo's meat was higher than female buffalo's meat at the age of less than one year and about a year, this was due to water holding capacity of male buffalo was higher than females at the same age (Table 5). The same result is expressed by Rao et al. (2009) and Kandeepan et al. (2009) that male buffalo's meat $\mathrm{pH}$ values was higher than female buffalo, probably due to the influence of production of lactic acid.

In all age groups except the male buffaloes at 1 to $1.5 \mathrm{yr}$ old had a $\mathrm{pH}$ value of meat was in the normal range (5.4 to 5.8). Although the age of male buffalo meat $\mathrm{pH}$ was above the ultimate $\mathrm{pH}$ values, but have not reached category DFD (dark, firm, dry) with a $\mathrm{pH}$ value of 6.9. The test results showed no differences in $\mathrm{pH}$ values between age groups and sex. $\mathrm{pH}$ values were not affected by age and sex after the meat was stored in the freezer for $7 \mathrm{~d}$, but the age affected the $\mathrm{pH}$ value prior to storage (Kandeepan et al., 2009; Rao et al., 2009; Andreas et al., 2010). A longer period of aging would reduce the $\mathrm{pH}$ value due to the concentration of glycogen and lactic acid increased (Neath et al., 2007a).

Decreased in $\mathrm{pH}$ was associated with glycogen content at slaughter. Stress conditions could reduce the content of glycogen in the muscles. Glycogen levels could lead to low glycolysis and then a slight accumulation of lactic acid, so the decreased in $\mathrm{pH}$ was also low. The final value of $\mathrm{pH}$ was not only influenced by glycogen. Aberle et al. (2001) suggested that changes in the $\mathrm{pH}$ of the cattle meat were very significantly affected by intrinsic factors such as species, muscle type, individual animals, and by extrinsic factors such as the handling of cattle before and after slaughter.

Table 5. $\mathrm{pH}$ value of buffalo meat at different sex and age

\begin{tabular}{cccccc}
\hline \multirow{2}{*}{ Sex } & \multicolumn{5}{c}{ Age } \\
\cline { 2 - 6 } & $8-12 \mathrm{mo}$ & $1.5 \mathrm{yr}$ & $2 \mathrm{yr}$ & $3 \mathrm{yr}$ & $4 \mathrm{yr}$ \\
\hline Female & $5.8 \pm 0.48$ & $5.5 \pm 0.12$ & $5.5 \pm 0.03$ & $5.2 \pm 0.63$ & $5.6 \pm 0.03$ \\
Male & $6.1 \pm 0.30$ & $6.2 \pm 0.83$ & $5.5 \pm 0.08$ & $5.2 \pm 0.08$ & $5.5 \pm 0.01$ \\
\hline
\end{tabular}

$\mathrm{pH}$ values also influence the physical characteristics of meat, such as water holding capacity, tenderness and cooking loss. There was a positive correlation $(\mathrm{P}<0.05)$ between the $\mathrm{pH}$ value and the shear force value of the female buffaloes. According to Aberle et al. (2001), the isoelectric $\mathrm{pH}$ of myofibrillar protein is the equal of the number of positively and negatively charged groups. $\mathrm{pH}$ values higher than the isoelectric point of meat protein, a positive charge was released and there was a surplus of negative charge which resulted in rejection of myofilamen and give more space for water molecules. Similarly, at $\mathrm{pH}$ lower than the isoelectric $\mathrm{pH}$, there would be an excess of positive charge that resulted in rejection myofilamen and give more space for water molecules. Decreased in $\mathrm{pH}$ would enhance contraction of actomyosin and increased cooking loss, whereas water holding capacity would decrease.

Water holding capacity. Water holding capacity is a reflection of the water-bound meat (Lonergan, 2010). The analysis showed that buffalo's meat was not influenced by age and sex (Table 6). The water holding capacity was not affected by age at slaughter and storage. It was related to the protein content of the meat so that the increased levels of protein would enhance water binding. Rao et al. (2009) revealed the water holding capacity was not affected by age, but were influenced by the sex and the storage period at 0,24 , and $48 \mathrm{~h}$.

Water holding capacity of male buffalo's meat was larger than females at the age of $1.5 \mathrm{yr}$. High water holding capacity could inhibite the juices of the meat caused decline of cooking loss. According to Rao et al. (2009), the declined in the water holding capacity in female buffalo's meat might be due to loss of fluid and protein ratios were high.

Water holding capacity is affected by $\mathrm{pH}$ and the amount of ATP. Final $\mathrm{pH}$ value was high could lead to greater water holding capacity (the smaller percentage of free water) in other words the rate of postmortem $\mathrm{pH}$ declined would affect the water holding capacity. The accelerated of declined $\mathrm{pH}$ occurred because more sarcoplasmic proteins were denatured and would further enhance actomyosin to contract so that it would squeeze the liquid out of the meat protein (Aberle et al., 2001).

Cooking loss. Cooking loss is the difference between the weights of meat before and after cooking. Fluid in the meat would melt out when heated, causing the weight of the meat to shrinked. Smaller value of cooking loss indicated that the meat quality was better, because less nutrients lost during cooking (Lonergan, 2010).

Table 6. Water holding capacity of buffalo meat at different sex and age $\left(\% \mathrm{mgH}_{2} \mathrm{O}\right)$

\begin{tabular}{ccccccc}
\hline \multirow{2}{*}{ Sex } & \multicolumn{7}{c}{ Aged } \\
\cline { 2 - 7 } & $8-12 \mathrm{mo}$ & $1.5 \mathrm{yr}$ & $2 \mathrm{yr}$ & $3 \mathrm{yr}$ & $4 \mathrm{yr}$ & Mean \\
\hline Female & $23.7 \pm 14.3$ & $13.9 \pm 16.1$ & $35.5 \pm 28.0$ & $14.7 \pm 12.4$ & $52.5 \pm 20.3$ & $28.1 \pm 22.0$ \\
Male & $38.2 \pm 49.6$ & $34.8 \pm 21.2$ & $17.7 \pm 22.5$ & $24.2 \pm 6.2$ & $33.5 \pm 12.5$ & $28.3 \pm 25.8$ \\
Mean & $30.9 \pm 33.6$ & $24.4 \pm 20.3$ & $28.4 \pm 24.8$ & $19.4 \pm 10.2$ & $42.5 \pm 26.0$ & $28.2 \pm 23.3$ \\
\hline
\end{tabular}


Table 7. Cooking loss of buffalo meat at different sex and age (\%)

\begin{tabular}{ccccccc}
\hline \multirow{2}{*}{ Sex } & \multicolumn{7}{c}{ Age } \\
\cline { 2 - 7 } & $8-12 \mathrm{mo}$ & $1.5 \mathrm{yr}$ & $2 \mathrm{yr}$ & $3 \mathrm{yr}$ & $4 \mathrm{yr}$ & Mean \\
\hline Female & $29.7 \pm 17.8$ & $41.5 \pm 3.6$ & $48.7 \pm 4.2$ & $45.3 \pm 5.3$ & $60.6 \pm 9.5$ & $45.2 \pm 13.2$ \\
Male & $42.4 \pm 3.6$ & $32.9 \pm 7.7$ & $47.1 \pm 8.3$ & $47.7 \pm 30.0$ & $46.3 \pm 2.3$ & $42.8 \pm 14.3$ \\
Mean & $36.0 \pm 13.4$ & $37.2 \pm 7.1$ & $48.1 \pm 5.2$ & $46.5 \pm 19.3$ & $54.9 \pm 10.4$ & $44.1 \pm 13.5$ \\
\hline
\end{tabular}

The results showed that cooking loss was not affected by age and sex (Table 7). Andreas et al. (2010) reported that age and sex did not affect the value of cooking loss of buffalo's meat. The situation was related to $\mathrm{pH}$ values that were also not significantly different between age and sex. $\mathrm{pH}$ value of male buffalo's meat at $1.5 \mathrm{yr}$ old was higher than that of female buffalo, improving water holding capacity which would increased the muscle's ability to bind water and produced low cooking loss. Aberle et al. (2001) stated that the decreased in $\mathrm{pH}$ caused by high temperatures could cause a reduction in the binding of water due to the increase of muscle protein denaturation and increase movement of water into the extracellular space and consequently increased the rate of meat cooking loss. Losses were also influenced by cooking time and cooking temperature. The high value of shrinkage was caused by the degree of damage to mature muscle fibers and coagulation proteins (Vasanthi et al., 2007).

\section{CONCLUSION}

The fiber muscle diameter is affected by age. Buffalo until the age of $1.5 \mathrm{yr}$ old has a diameter of muscle fiber of $37.37 \pm 8.0 \mu \mathrm{m}$ and buffalo with over $3 \mathrm{yr}$ old has a diameter of muscle fiber of $54.95 \pm 8.6 \mu \mathrm{m}$. Diameter of fasciculus, thickness of the connective tissue, $\mathrm{pH}$, cooking loss, water holding capacity, and tenderness are not affected by sex and age. Buffaloes slaughtered at different ages (2-4 yr) produce almost the same quality of meat.

\section{ACKNOWLEDGMENT}

This research was supported by Ministry of Agriculture Republic of Indonesia through the KKP3T 2009 project with contract no. 637/LB.620/I.1/2/2009. We would like to thanks to Directorate General of Livestock Services (DGLS)-Ministry of Agriculture for giving permission collecting buffalo's meat samples in Banten Province.

\section{REFERENCES}

Aberle, E. D., J. C. Forrest, D. E. Gerrard, E. W. Mills, H. B. Hedrick, M. D. Judge, \& R. A. Merkel. 2001. Principles of Meat Scince. $4^{\text {th }}$ ed. Kendall Hunt Publishing Company, Iowa.

AOAC. Association of official Analytical Chemist. 1995. Official Method of Analysis of Association Analytical Chemist. $14^{\text {th }}$ ed. AOAC inc, Arlington.

Andreas, E. C. Sumantri, H. Nuraini, A. Farajalah, \& A. Ang- graeni. 2010. Identification of GH/ALUI and GHR/ALUI genes polymorphisms in Indonesian Buffalo. Journal of the Indonesian Tropical Animal Agriculture. 35:215-221.

Belew, J. B., J. C. Brooks, D. R. McKenna, \& J. W. Savell. 2003. Warner-Bratzler shear evaluations of 40 bovine muscles. Meat Sci. 64:507-512. http://dx.doi.org/10.1016/S03091740(02)00242-5

Choi, Y. M. \& B. C. Kim. 2009. Muscle fiber characteristics, myofibrillar protein isoforms, and meat quality. Livestock Sci. 122: 105-118. http://dx.doi.org/10.1016/j.livsci.2008.08.015

Francisco, C. L., A. M. Jorge, M. Dal-Pai-Silva, F. R. Carani, L. C. Cabeço, \& S. R. Silva. 2011. Muscle fiber type characterization and myosin heavy chain $(\mathrm{MyHC})$ isoform expression in Mediterranean buffaloes. Meat Sci. 88:535-541. http://dx.doi.org/10.1016/j.meatsci.2011.02.007

Hamm, R. 1972. Kolloidchemie des fleisches des wasserbindungsvermoegen des muskeleiweissess in theorie und praxis. Verlag Paul Parey, Berlin.

Kandeepan, G., S. Biswas, \& K. Porteen. 2006. Influence of histological changes of refrigerator preserved buffalo meat on quality characteristics. Journal of Food Technology 4:116121.

Kandeepan, G., A. S. R. Anjaneyulu, N. Kondaiah, S. K. Mendiratta, \& V. Lakshmanan. 2009. Effect of age and gender on the processing characteristic of buffalo meat. Meat Sci. 83:10-14. http://dx.doi.org/10.1016/j.meatsci.2009.03.003

Kiernan, J. A. 1990. Histological and Histochemical Method: Theory and Practice. $2^{\text {nd }}$ ed. Pergamon Press. Pp. 170-197.

Kumar, M. M. \& G. Thulasi. 2011. Effect of electrical stimulation on biochemical characteristics and tenderness of buffalo meat. The Indian J. Anim. Sci. 76:971-973.

Lonergan, E. H. 2010. Water Holding Capacity of Fresh Meat. National Pork Board/ American Meat Science Association Fact Sheet, Iowa State University.

Neath, K. E., A. N. Del Barrio, R. M. Lapitan, J. R. V. Herrera, L. C. Cruz, T. Fujihara, S. Muroya, K. Chikuni, M. Hirabayashi, \& Y. Kanai. 2007a. Difference in tenderness and $\mathrm{pH}$ decline between water buffalo meat and beef during postmortem aging. Meat Sci. 75: 499-505. http://dx.doi. org/10.1016/j.meatsci.2006.08.016

Neath, K. E., A. N. Del Barrio, R. M. Lapitan, J. R. V. Herrera, L. C. Cruz, T. Fujihara, S. Muroya, K. Chikuni, M. Hirabayashi, \& Y. Kanai. 2007b. Protease activity higher in postmortem water buffalo meat than Brahman beef. Meat Sci. 77: 389-396. http://dx.doi.org/10.1016/j.meatsci.2007.04.010

Naveena, B. M., M. Kiran, K. S. Reddy, C. Ramakrishna, S. Vaithiyanathan, \& S. K. Devatkal. 2011. Effect of ammonium hydroxide on ultrastructure and tenderness of buffalo meat. Meat Sci. 88: 727-732. http://dx.doi.org/10.1016/ j.meatsci.2011.03.005

Palka, K. 2003. The influence of post-mortem ageing and roasting on the microstructure, texture and collagen solubility of bovine semitendinosus muscle. Meat Sci. 64:191-198. http://dx.doi.org/10.1016/S0309-1740(02)00179-1

Rao, C. A., G. Thulasi, \& S. W. Ruban. 2009. Meat quality characteristics of non-descript buffalo as affected by age and sex. J. World Appl. Sci. 6:1058-1065. 
Sen, A. R. \& N. Sharma. 2004. Effect of freezing and thawing on the histology and ultrastructure of buffalo muscle. J. Anim. Sci. 17:1291-1295.

Spanghero, M., L. Gracco, R. Valusso, \& E. Piasentier. 2004. In vivo performance, slaughtering traits and meat quality of bovine (Italian Simmental) and buffalo (Italian Mediterranean) bulls. Livestock Product. Sci. 91: 129-141. http:// dx.doi.org/10.1016/j.livprodsci.2004.07.013

Steel, R. G. D. \& J. H. Torrie. 1991. Prinsip dan Prosedur Statistika. Terjemahan Bambang S. PT Gramedia Pustaka Utama, Jakarta.
Vasanthi, C., V. Venkataramanujam, \& K. Dushyanthan. 2007. Effect of cooking temperature and time on the physicochemical, histological and sensory properties of female carabeef (buffalo) meat. Meat Sci. 76:274-280. http://dx.doi. org/10.1016/j.meatsci.2006.11.018

Xiong, Y. L., O. E. Mullins, J. F. Stika, J. Chen, S. P. Blanchard, \& W. G. Moody. 2007. Tenderness and oxidative stability of post-mortem muscles from mature cows of various ages. Meat Sci. 77:105-113. http://dx.doi.org/10.1016/ j.meatsci.2007.04.012 